\title{
乳幼児期の発達と地域の特性
}

一沖縄(宮古・八重山群島)の乳幼児の発達一

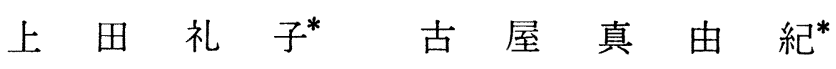

\section{Characteristics of Child Development in Okinawa; The Comparisons with Tokyo and Denver and the Implications for the Developmental, Screening.}

\section{Reiko UEDA*, Mayuki FURUYA*}

Developmental differences in the Denver Developmental Screening Test items were demonstrated between the 615 Okinawa(Miyako and Yaeyama Islands) children and the 1171 Tokyo children. The children in Tokyo were generally advanced than those in Okinawa after one year of age, while the children in Okinawa demonstrated earlier development in the middle and late periods of the first year.

There were also interesting differences between Okinawa and Denver. Okinawa children were initially slow in gross motor development. Denver children were markedly advanced in some of the language items. Ecological and socio-cultural factors which may contribute to these differences as well as the implications of these results for the developmental screening were discussed.

\section{1.はじめに}

人間の乳幼児期の発達に文化・社会・地理 的な差異が関与していることが知られている (Hindley, C. B., Super, C. M., Brazelton, T. B. B)。また，ある都市における社会・経 済的要因や人種の差異が乳幼児の発達の様相 にどのように影響しているかにつき検討した 報告もみられる (Frankanburg, W. K. K $^{4}$ )。
著者らは日本が地理的に特に南北に長い立 地条件にあることから, 発達における地域差 に注目して検討してきている (上田他 ${ }^{5)}$ )。

この研究の目的はこれまでの知見に基づき, 宮古・八重山群島の乳幼児の発達を東京都の 乳幼児の発達と比較して, その類似性と差異 を明らかにし，発達に関与する地域差につい て検討し，同時に，それらが発達スクリーニ ングに際してもつ意味を明らかにすることで

* 東京大学医学部保健学科母子保健学教室 (主任教授平山宗宏)

*Dept. of maternal and Child Health, School of Health Sciences, Faculty of medicine, University of Tokyo. 
ある。

\section{2. 対象と方法}

対象地域の宮古群島・八重山群島は図 1 に 図 1
示す如く地理的に台湾に近く, 沖縄本島より さらに南西に位置し，宮古本島を中心とした 周辺の離島と石垣島を中心とした八重山諸島 からなっている。一方の対照地域である東京
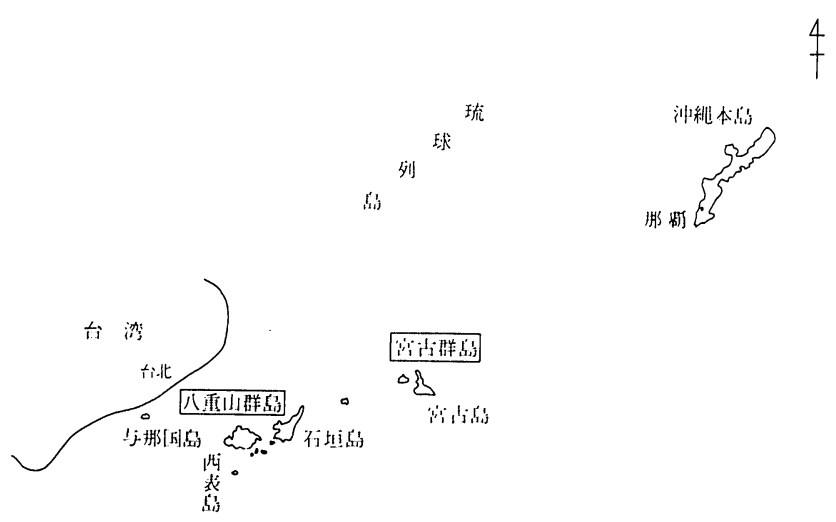

都とは23区とその周辺部・島部を含む東京都 全域である。

対象児は宮古・八重山群島 (沖縄)の乳幼児 であるが, 1975年〜1977年の間に3回実施され た乳幼児集団健診に訪れた者の中から年月秢 グループと性別にかたよりなく，次の条件を 満たすものをサンプルとした。すなわち, 年 月粭の範囲は生後16日から 6 歳 6 力月までの 者であり，養子，未熟児，双生児，骨盤位出 生児, 口蓋裂児でなく, 聴賞·視覚·中枢神経 系に明らかな障害の認められないものである。 対照児はデンバー式発達スクリーニング用検査 の標準化の際のサンプルと同じものである。

発達測定のために使用した検査は著者らが

日本の子ども用に標準化した発達スクリーニング用 検查である。Personal-social, Fine motorAdaptive, Language, Gross motor 領域の 104の検査項目から構成されている観察・面 接法による検査である。

検査結果の処理にはProbit法を用い,それぞ れの項目を $25 \%, 50 \%, 75 \%, 90 \%$ 子どもが通過 する年月秢を算出した。次に, 50 ゚゚ーンタイル と90パーセンタイルについて宮古・八重山群と東京 都群とを比較し,さらに,宮古・八重山群とデンバ 一市の乳幼児の成績とを比較する方法をとった。

\section{3. 結果}

\section{1）沖縄群と東京都群の比較}

Table 1 Occupation of Fathers

\begin{tabular}{l|rr|rr}
\multirow{2}{*}{ Classification } & \multicolumn{2}{|c|}{ Okinawa } & \multicolumn{2}{c}{ Tokyo } \\
\cline { 2 - 5 } & \multicolumn{1}{|c|}{ No. } & \multicolumn{1}{c|}{$\%$} & \multicolumn{1}{c}{ No. } & \multicolumn{1}{c}{$\%$} \\
\hline Managers and professionals & 51 & 8.3 & 195 & 16.7 \\
$\begin{array}{l}\text { Clerical and related } \\
\text { workers }\end{array}$ & 97 & 15.8 & 277 & 23.7 \\
$\begin{array}{l}\text { Sales workers } \\
\text { Farmers, fishermen, }\end{array}$ & 29 & 4.7 & 186 & 15.9 \\
$\begin{array}{l}\text { workers in transport } \\
\text { and communication, etc. }\end{array}$ & 358 & 58.2 & 401 & 34.2 \\
$\begin{array}{l}\text { Service workers } \\
\text { Others and unknown }\end{array}$ & 43 & 7.0 & 91 & 7.8 \\
\multicolumn{1}{c}{ Total } & 615 & 6.0 & 21 & 1.7 \\
\hline
\end{tabular}


対象児の父親の職業は表 1 に示す如くであ り, 宮古・八重山群の父親の58.2\%は農業, 漁業, 運輸関係などの仕事であり，管理・専 門，事務の仕事に従事しているものは $24.1 \%$

Tabrle 2 Education of Mothers

\begin{tabular}{l|rc|rc}
\hline \multirow{2}{*}{ Classification } & \multicolumn{2}{|c|}{ Okinawa } & \multicolumn{2}{c}{ Tokyo } \\
\cline { 2 - 5 } & \multicolumn{1}{c|}{ No. } & $\%$ & No. & $\%$ \\
\hline More than high school & 64 & 10.4 & 275 & 23.5 \\
High school & 149 & 24.2 & 546 & 46.6 \\
Less than high school & 370 & 60.2 & 277 & 23.7 \\
Unknown & 32 & 5.2 & 73 & 6.2 \\
\hline \multicolumn{1}{c|}{ Total } & 615 & 100.0 & 1171 & 100.0
\end{tabular}

各検査項目について $50 \%$ を通過する月鯩を 宮古・八重山群と東京都群の間で比較した結
であった。また，宮古・八重山群では，父親 の $48.9 \%$ ，母親の $60.2 \%$ が義務教育終了者で あったが,一方, 東京都群では義務教育終了 が父親に $21.3 \%$ ，母親に23.7\%あった。(表 $2 ，$

Table 3 Education of Fathers 表 3 )

\begin{tabular}{|c|c|c|c|c|}
\hline \multirow{2}{*}{ Classification } & \multicolumn{2}{|c|}{ Okinawa } & \multicolumn{2}{|c|}{ Tokyo } \\
\hline & No. & $\%$ & No. & $\%$ \\
\hline More than high school & 68 & 11.1 & 408 & 34.8 \\
\hline High school & 210 & 34.1 & 443 & 37.8 \\
\hline Less than high school & 301 & 48.9 & 249 & 21.3 \\
\hline Unknown & 36 & 5.9 & 71 & 6.1 \\
\hline Total & 615 & 100.0 & 1171 & 100.0 \\
\hline
\end{tabular}

果は表 4 の如くであった。104の検査項目の うち，22項目が50\%通過月粭において $5 \%$ の

Table 4 Comparison between Tokyo and Okinawa -Items significantly different at $50 \%$ passing

\begin{tabular}{|c|c|c|}
\hline Items & \multicolumn{2}{|c|}{ Age when $50 \%$ pass } \\
\hline $\begin{array}{l}\text { Personal - Social } \\
\text { Buttons up** }\end{array}$ & $36.5 \mathrm{mo}$. & $39.5 \mathrm{mo}$. \\
\hline $\begin{array}{l}\text { FINE MOTOR-ADAPTIVE } \\
\text { Grasps rattle }{ }^{* *} \\
\text { Rakes raisin, attains } \\
\text { Scribbles spontaneously }{ }^{* *} \\
\text { Imitates square, demonst. } \\
\text { Copies square }\end{array}$ & $\begin{array}{r}2.7 \\
6.5 \\
12.2 \\
53.6 \\
61.3\end{array}$ & $\begin{array}{r}3.2 \\
5.5 \\
13.7 \\
58.1 \\
69.0\end{array}$ \\
\hline $\begin{array}{l}\text { LANGUAGE } \\
\text { Gives first and last name } \\
\text { Comprehends } 3 \text { prepositions } \\
\text { Recognizes } 3 \text { colours } \\
\text { Opposite analogies, } 2 \text { of } 3^{*} \\
\text { Define } 3 \text { words } \\
\text { Compositions of }\end{array}$ & $\begin{array}{l}33.1 \\
42.2 \\
39.5 \\
40.2 \\
53.0 \\
59.8\end{array}$ & $\begin{array}{l}36.0 \\
45.4 \\
46.4 \\
42.7 \\
58.5 \\
66.7\end{array}$ \\
\hline $\begin{array}{l}\text { GROSS MOTOR } \\
\text { Bears some weight on legs ** } \\
\text { Stands holding on }{ }^{* *} \\
\text { Pulls self to stand* } \\
\text { Gets to sitting** } \\
\text { Stands alone well* } \\
\text { Stoops and recovers } \\
\text { Throws ball overhand } \\
\text { Jumps in place** } \\
\text { Balance on } 1 \text { foot } 10 \text { seconds }^{*} \\
\text { Backward heel-toe }\end{array}$ & $\begin{array}{r}4.9 \\
7.8 \\
8.2 \\
8.6 \\
11.5 \\
12.4 \\
24.0 \\
24.7 \\
54.1 \\
59.5\end{array}$ & $\begin{array}{r}4.2 \\
6.6 \\
7.2 \\
7.5 \\
11.1 \\
11.9 \\
21.8 \\
28.7 \\
58.6 \\
68.2 \\
\end{array}$ \\
\hline
\end{tabular}


有意水準で両群に差がみられたが，1\%の有 意水準では11項目に差が認められるにすぎな かった。粗大運動頒域では宮古・八重山群が “両足に体重をかける”, “つかまって立ってい る”, “ひとりですわれる”の項目で東京都群 より早く，また，微細一適応領域では“ひっ かくようにほしぶどうをひろいあげる”の項 目で東京都群より早かった。これらの項目は すべて乳児中期〜後期の項目である。一方， 東京都群は乳児期に 1 項目“ガラガラを握る” で早かった。しかし，満1歳をすぎると，粗 大運動の 1 項目を除いて全ての発達領域, す
なわち，個人一社会，微細一適応，言語，粗 大運動の領域において東京都群の方が宮古・ 八重山群に比較して有意に早い結果であった。

\section{2 ) 沖縄群とデンバー群の比較}

宮古・八重山群について今回得られた成績 を同じ検査法による米国デンバー市の乳幼児， の発達成績と比較して，その特徴を検討した。 デンバー市の発達成績は1975年手引書の数字 を使用し，宮古・八重山群とデンバー群につ き $50 \%$ および $90 \%$ の通過月粭を比較し，両方 とも $20 \% ， 30 \%$ 差のあった項目は表 5 に示 す如くであった。

Table 5 Okinawa and Denver Children compared for Age Differences when 50 and 90 Percent of Population pass Items

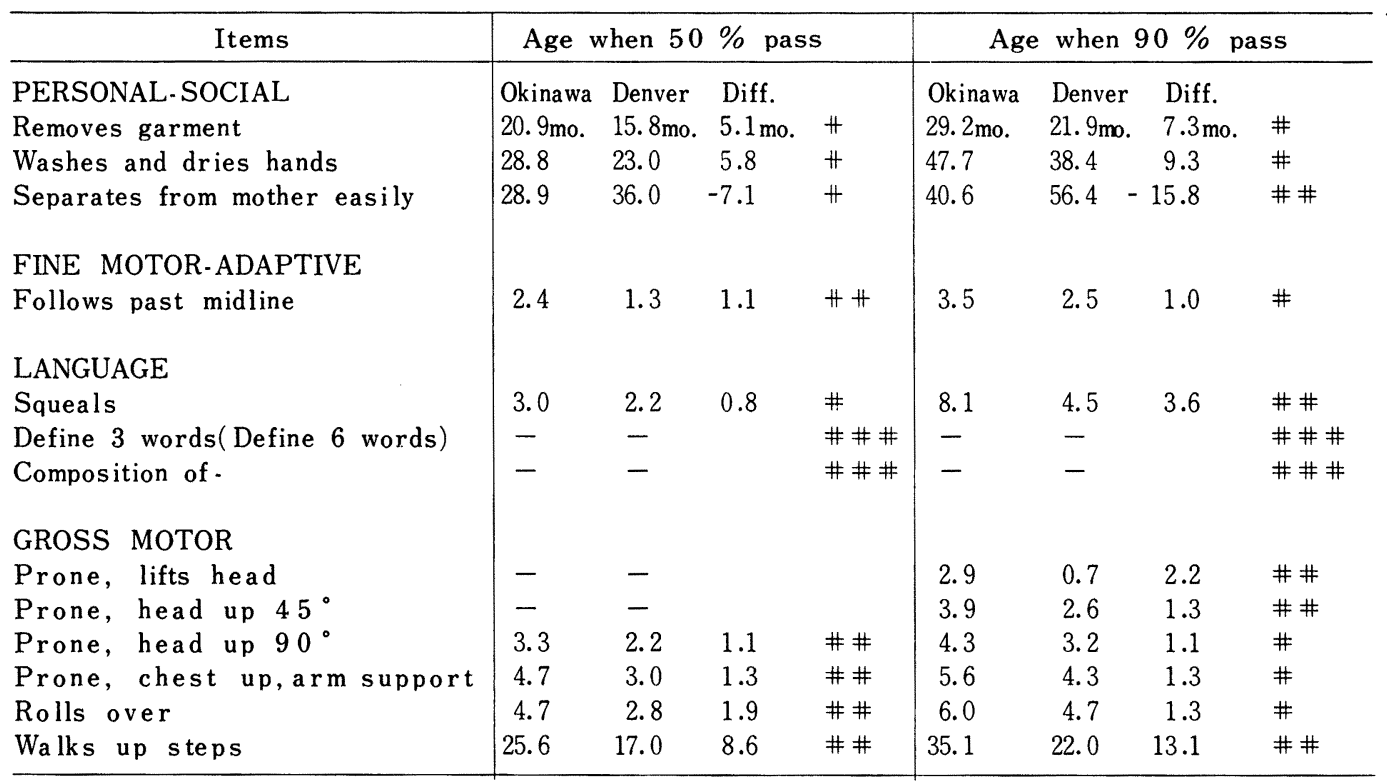

\footnotetext{
\#\# \# Items which had to be modified.

\# \# Difference more than $30 \%$ between Okinawa and Denver \# Difference more than $20 \%$ between Okinawa and Denver
}

\{すなわち, 沖縄群の $50 \%$ の過過月齿を Aとし, デンバー群の $50 \%$ の通過月粭を Bとすると， その差は次の式によって計算されたものであ る。差 $(\%)=\mathrm{A}-\mathrm{B} / \mathrm{A} \times 100\}$ 。また，表 5 にはDDST (Denver Developmental Scr. eening Test) の標準化の際に,すでに日本 の子ども用に修正された言語領域の 2 項目も
差のあった項目として含まれている。しかし， 50パーセンタイルにおいて沖縄群の方が早いが, 90パーセンタイルでデンバー群の方が早かっ た一項目は除外した。

特徵的なことは沖縄群が乳児初期の粗大運 動領域においてデンバー群に比較して遅い傾 向にあったことである。しかし，幼児期の個 
人一社会領域において沖縄群は“母親から容 易に離れる”項目でデンバー群より早かった。 また，その他の領域においてみられた差異は 言語領域において著しく，東京都の幼児の場 合と同様に，2 項目でデンバー市の幼児の評 価基準をかえる必要があった。そして，その 差は東京都とデンバー市との差よりも大きか った。

\section{4. 考察}

1)宮古・八重山地域の乳幼児の発達特徵を知 る目的で，東京都およびデンバー市の乳幼児 の発達と比較して検討したが，ここで得られ た発達上の差異については生物学的問題もさ ることながら，子どもの住む地域の物理・地 理的環境と文化・社会的背景の相違を考慮す る必要があるであろう。

対象児の身体的要因については表 6 にみら れる如くであり，母親の好娠・出産および子

Table 6

Prenatal-Perinatal-Neonatal Disturbances

\begin{tabular}{l|rr|rr}
\hline \multirow{2}{*}{ Classification } & \multicolumn{2}{|c|}{ Okinawa } & \multicolumn{2}{c}{ Tokyo } \\
\cline { 2 - 5 } & No. & $\%$ & No. & \multicolumn{1}{c}{$\%$} \\
\hline Pregnancy & & & & \\
No trouble & 584 & 95.0 & 1027 & 87.7 \\
Trouble & 23 & 3.7 & 41 & 3.5 \\
Unknown & 8 & 1.3 & 103 & 8.8 \\
\hline Total & 615 & 100.0 & 1171 & 100.0 \\
& & & & \\
Delivery & & & & \\
No trouble & 567 & 92.2 & 1098 & 93.8 \\
Trouble & 33 & 5.4 & 57 & 4.9 \\
Unknown & 15 & 2.4 & 16 & 1.4 \\
\hline Total & 615 & 100.0 & 1171 & 100.0 \\
& & & & \\
Neonatal & & & & \\
No trouble & 586 & 95.3 & 1024 & 87.4 \\
Trouble & 22 & 3.6 & 80 & 6.8 \\
Unknown & 7 & 1.1 & 67 & 5.7 \\
\hline Total & 615 & 100.0 & 1171 & 100.0
\end{tabular}

どもの新生児期において何らかの異常のあっ たものの占める割合を両群について比較する と, 推計学的に有意な差は認められなかった。
しかし，父親の職業や両親の教育歴および子 どもの出生順位において差が認められた。そ して，沖縄群では第 1 子・第 2 子が $63.6 \%$ を 占めているのに対して，東京都群では $84.9 \%$ であった。(表 7)

Table 7 Birth Order of Sample

\begin{tabular}{c|rc|cc}
\hline \multirow{2}{*}{ Birth order } & \multicolumn{2}{|c|}{ Okinawa } & \multicolumn{2}{c}{ Tokyo } \\
\cline { 2 - 5 } & \multicolumn{1}{|c|}{ No. } & \multicolumn{1}{c}{$\%$} & No. & $\%$ \\
\hline 1 & 236 & 38.4 & 594 & 50.7 \\
2 & 155 & 25.2 & 401 & 34.2 \\
3 & 106 & 17.2 & 144 & 12.3 \\
4 & 67 & 10.9 & 16 & 1.4 \\
5 & 30 & 4.9 & 1 & 0.1 \\
6 & 9 & 1.5 & 3 & 0.3 \\
7 & 2 & 0.3 & 0 & 0 \\
8 or over & 3 & 0.5 & 0 & 0 \\
Unknown & 7 & 1.1 & 12 & 1.0 \\
\hline Total & 615 & 100.0 & 1171 & 100.0
\end{tabular}

また，核家族は宮古・八重山群では73.0\%で あり，東京都群では $85.1 \%$ であった。

乳幼児期の養育方法についてみると，乳児 初期に子どもを仰臥位にねかせておくなどの 一般的な世話の仕方は沖縄地方と東京地方と に違いはない。しかし, 宮古・八重山地方の 母親は乳児のおむつを早くとり，排泄をさせ るために一日に数回もだきあげるということ， また，子どもを立たせたり，歩かせたりする ことを乳児中期からやらせる傾向があった。 一方， 1 年を通して東京より気温が高く, 着 衣が少ないということは乳児の自発的運動に 有利に作用しているようである。そして，こ れらの環境要因が乳児中期から後期にかけて の宮古・八重山群の運動発達に有利に作用し ていると推定される。

しかしながら，宮古・八重山地域の乳幼児 の発達速度（増加率）は満 1 才をすぎると東 京都地域に比べて一般に遅くなっている。こ の理由の一つとしては一世帯の子どもの数が 2.4 人と東京都の 1.8 人に対して多く，そのた 
めに，母親の関心が乳児期をすぎた 1 人の子 どもに集中されることは少なくなり，年上の 同胞や祖父母などによって世話されるように なることと関係していると推測される。また， 言語領域の項目の成績にみられた両群の違い には, 検査課題や検査者も含めて被験児の中 には検査場面への適応に困難のあった者もあ ることも考虑しなければならないであろうう。

これらの事実は, 乳幼児の発達スクリーニ ングを実施する際に, 宮古・八重山地域の乳 幼児のこのような発達上の地域差を考慮する 必要があることを示㖫している。そして, も し，それが無視されれば，乳児期にはf fal se negatives (under-referrals) の危険と幼児 期にはfalse positives( over-referrals)の 危険が予想されるのである。

2)宮古・八重山地域とデンバー市の乳幼児と の間にみられた発達上の差異は環境要因によ り一部説明が可能である。すなわち，個人一 社会の領域において沖縄の幼児がデンバー市 の幼児に比較して“母親から容易に離れられ る”の項目で早い值を示している理由は乳幼 児が母親から離れる時にベビー・シッター や知らない人に世話されるという習慣はなく， 家族や身内の者と一緒であることと関係して いるであろう。

また, 乳児前期の粗大運動領域の発達と幼 児期における言語領域の 2 項目において沖縄 群がデンバー群に比較しておそかったことは 東京都群とデンバー市群を比較した際にも観 察されたことである。つまり乳児前期に粗大 運動発達のおそい理由については日本と米国 との乳児の養育方法の違いが考えられ，幼児 期の言語領域の 2 項目のおそいことについて は日本人と西洋人との間にある言語表現の文 化的差異汇もとづくものと考えられる。

\section{5.まと め}

宮古・八重山諸島（沖縄）の乳幼児615 名 を対象として，デンバー式発達スクリーニング
用検査を実施し，その結果を東京都の1171名 の乳幼児の成績と比較して発達の差異を検討 した。一般に，沖縄群は乳児中期〜後期にお いて東京群よりもはやい傾向にあり, 一方, 東京群は幼児期において沖縄群よりも早いと いう傾向を示した。

また, 沖縄群と米国デンバー市群とを比較す ると興味ある結果がみられた。すなわち, 沖 縄群は乳児初期の全体運動領域の発達がおそ く, デンバー市群は幼児期の言語領域の2項目 で著しく早かった。これらの差異の生じた理 由について生態学的な視点から考察し, さら に，これらの差異が乳幼児の発達スクリーニ ングに際してもつ意味について論じた。

附記）この研究は1977年度の文部省科学研究费 の援助を得て実施しました。 本調査にご協力いただいた 50 年度, 51年 度，52年度宮古島・八重山乳幼児健診班 の諸先生ならびに宮古保健所・八重山保 健所の職員の方々,資料収集に一部協力い ただいた川井尚氏に深謝いたします。なお， 本論文の要旨は第42回日本民族衛生学会 (東京, 1977年10月)およびThe Second International Conference on Deuelopmental Screening( Santa Fe, new mexico, Sept. 1977）にて発表しました。

\section{参 考 文 献}

1) Hindley, C. B. : 'Growing up in five countries: A comparison of data on weaing, elimiation training, age of walking and ID in relation to social class from $\mathrm{E}$ uropean longitudinal studies, 'Develop. Med. Child Neurol., 10, 715-724,1976

2) Super, C. M. 'Environmental effecis on motor development: the case of African infant precocity, 'Develop. Med. Child Neurol., 18, 561-567, 1976

3 ) Brazelton, T. B. et al. 'Infant development in the Zinacanteco Indians of 
Southern Mexico,' Pediatrics, 44(2), 274-290, 1969

4) Frankenburg, W. K. et al . 'Development of preschool-aged children of different social and ethnic groups; Implications for developmental screening, 'J. of Pediatrics, 87(10), 125-132, 1975

5）上田礼子, 山本早苗：乳幼児期の発達と 地域の特性一宮古島の乳幼児の発達一, 小 児科診療，39(1)，73〜 79，1976

6）上田礼子他：デンバー式発達検査の標準 化に関する研究, 小児保健研究，36(2), 81-86, 1977

7) Frankenburg, W. K. et al. Denver developmental screening test reference manual. Denver, University of Colorado Medical Center, 1975
8）山岡浩一：乳幼児期に於ける基本的運動 機能発達に関する研究, 福岡医学雑誌, 2182 2183，1957

9. 上田礼子他：乳幼児発達検査の標準化に 関する研究(1)-24力月までの標準化一, 総合リハビリ，4(8), 41〜46, 1976

10）上田礼子他：乳幼児発達検査の標準化に 関する研究(2)-24 月から 6 歳 6 力月まで の標準化，総合リハビリ，5(9)，679６84， 1977

11）土扂健郎：甘えの構造，83～94, 弘文堂, 1972

12) Burnlund, D. C., 西山干訳：日本人の 表現構造, 15, サイマル出版会, 1973 